\title{
Yoga Pranayama Increases Peak Expiratory Flow (PEF) in Patient with Asthma
}

\author{
Made Mahaguna Putra \\ Master Student Faculty of Nursing, Universitas Airlangga \\ Surabaya, Indonesia \\ Made.mahaguna-2016@ fkp.unair.ac.id
}

\author{
Sriyono \\ Faculty of Nursing, Universitas Airlangga \\ Surabaya, Indonesia \\ sriyono@fkp.unair.ac.id \\ Deni Yasmara \\ Faculty of Nursing, Universitas Airlangga \\ Surabaya, Indonesia \\ Deny-y@fkp.unair.ac.id
}

\begin{abstract}
Patients with asthma will experience a decrease in pulmonary function due to airway obstruction. Yoga Pranayama is a practice of meditation, self-hypnosis with positive suggestions and breathing exercise for patients with asthma that can cause optimal ventilation. This study was to explain the effect of Yoga Pranayama to pulmonary function improvement of patients with asthma in Puskesmas IV Denpasar Selatan. The study was using a quasiexperimental design with two group pre-post test design. The population was patient with asthma in Puskesmas IV Denpasar Selatan with a total sample of 12 patients, consisted of 6 patients for intervention group dan six patients for the control group. The independent variable was Yoga Pranayama. The dependent variables were Peak Expiratory Flow Rate (PEF) and Oxygen Saturation (SaO2). Instruments were peak flow meter and pulse oximetry. Results showed that there was a significant difference in PEF ( $p=0.00)$, but there was no significant effect on the value of $\mathrm{SaO} 2$ (p=0.10). Yoga Pranayama can increase tidal volume. As a result the value of PEF increased. Future study may use spirometry and blood gas analyze for specific measuring the PEF and $\mathrm{SaO2}$.
\end{abstract}

Keyword: Asthma, Oxygen Saturation, Pulmonary Function, Yoga Pranayama

\section{INTRODUCTION}

Asthma is a chronic inflammatory airway disease characterized by episodic wheezing, cough and dyspnea as a result of airway obstruction [1]. The incidence of asthma increased dramatically for more than fifteen years, both in developing countries and in developed countries. The adverse effects of asthma include decreased quality and productivity, absence in schools, increased health care costs, the risk of hospitalization and even death [2] and decreased in lung function [3]. Research has revealed a decrease in lung function in individuals with asthma permanently or history of asthma in children and young adults. Chronic airway inflammation can cause a long-term decrease in lung function in asthma patients [4]. Every year there are more than 180,000 deaths worldwide due to this condition, and asthma becomes a more serious disease in recent years [5]. The decrease in lung function in asthma patients happens compared with healthy people [6].

Based on data from WHO, there are approximately 100150 million people suffered from asthma in the world. Those number of patients continue to rise as much as 180,000 annually [7]. RISKESDAS 2013 shows the number of asthma patients in Indonesia amounted to $4.5 \%$, the number of events that occurred in the province of Bali by $6.2 \%$ [8]. Asthma in developing countries, such as in Indonesia, is still a chronic airway disease which is become a serious public health problem. Also, asthma symptoms can interfere with daily life causes a person can not perform activity optimally [9]. In asthma there are bronchiolus muscle spasms that can cause shortness of breath, difficulty in expiration, decreased lung capacity and the physical condition becomes weak [10]. Yoga Pranayama is the practice of breathing control and breathing techniques consciously, making breathing smooth and soft. Long breathing, pauses between inhalation and respiratory is eliminated. It helps in controlling the mind and concentration (dharana) [11]. Kondam study showed a significant increase in some lung function parameters of the intervention group after 6-weeks practice Yoga Pranayama [12]. Results of research by Mariya showed there was a significant improvement in all parameters of lung function except FVC compared with physiotherapy. Parmar \& Nagarwala in his research showed a significant increase of FEV1 and PEF in lung function tests in people with asthma who did Yoga Pranayama [5].

Yoga Pranayama exercises can optimize ventilation so that peak expiratory flow will increase automatically. The increase in peak expiratory flow will increase oxygen partial pressure in alveoli and causing diffusion in alveoli and capillaries increases. The decrease in $\mathrm{CO} 2$ and $\mathrm{O} 2$ occurs along with an increase in diffusion of alveoli and capillaries so that oxygen saturation increases.

\section{METHOD}

This research was used quasi-experiment pre and post test with control group design. Total of samples in this study were 12 people with the inclusion criteria 1) asthma patients with moderate to severe degree, 2) Aged 20-45 years old, 3) Patients with asthma who consumes salbutamol while an exclusion criterion in this study was: 1) Pregnant/lactating, 2) Patients with asthma who had heart attack, 3) size of the finger is too large or small, 4) Patients with asthma who experience influenza. This study was used nonprobability sampling technique type of purposive sampling. The 
independent variables in this study were Yoga Pranayama exercise while the dependent variable in this study was peak expiratory flow (PEF) and Oxygen Saturation (SaO2).

This study took place at the Puskesmas IV South Denpasar on 13th May - 4th Juni 2015. The instrument used is a peak flow meter and pulse oximetry to measure PEF and $\mathrm{SaO} 2$ which were given at pre and post test in both groups. Data were analyzed using Paired t test and Independent $t$ test. The first analysis was Paired t test if $p$ value $\leq 0.05$ then $\mathrm{H} 1$ accepted, which means that Yoga Pranayama affecting PEF. While $\mathrm{H} 2$ rejected, which means Yoga Pranayama does not affect $\mathrm{SaO} 2$ and the second test was Independent $t$ test to analyze the differences in the value of PEF and $\mathrm{SaO} 2$ post intervention in both groups. This study has passed the ethical test in Faculty of Nursing Universitas Airlangga.

\section{RESULT}

Effect of Yoga Pranayama in PEF and $\mathrm{SaO} 2$ value can be seen in the results of paired test between pre and post intervention measurements that is 0.03 and 0.62 . $\mathrm{P}$ value < 0.05 means that $\mathrm{H} 1$ accepted, which means there was significant difference between Yoga Pranayama exercises in $\mathrm{PEF}$, while in $\mathrm{SaO} 2 \mathrm{p}$ value $>0.05$ means $\mathrm{H} 2$ rejected, which means there was no significant relationship between Yoga Pranayama exercises in $\mathrm{SaO} 2$. In control group showed no differences in PEF and $\mathrm{SaO} 2$ values, this is indicated by the statistical test result with $\mathrm{p}$ value $=0.62$ and 0.28 . This value was $>0.05$, which means there was no change in PEF and $\mathrm{SaO} 2$ in control group. Table 1.1 also shows the results of statistical analysis tests (post intervention value) of PEF and $\mathrm{SaO} 2$ in intervention and control group using independent $\mathrm{t}$ test with value $=0.00$ and 0.10 . The value of $<0.05$ means that there was effect of Yoga Pranayama exercises in APE.

\section{DISCUSSION}

\section{A. EFFECT OF YOGA PRANAYAMA IN PEF}

Statistical analysis showed that Yoga Pranayama exercises influence significantly in decreasing the difference in peak expiratory flow (PEF) of patients with asthma, causing decrease of peak expiratory flow (PEF) daily variability value in intervention group $(\mathrm{P}=0.03, \alpha=0.05)$, Table 5.10 describes the results of Independent t test and obtained Peak Expiratory Flow (PEF) between the intervention and control groups is different with $\mathrm{P}=0.00, \alpha=0.05$.

TABLE I. DISTRIBUTION OF PEF AND SAO2 BEFORE AND AFTER YOGA PRANAYAMA EXERCISES IN PUSKESMAS IV SOUTH DENPASAR ON 13TH MAY - 4TH JUNI 2015

\begin{tabular}{ccccc}
\hline \multirow{2}{*}{ Variable } & \multicolumn{4}{c}{ Group } \\
\cline { 2 - 5 } & \multicolumn{2}{c}{ Intervention } & \multicolumn{2}{c}{ Control } \\
\cline { 2 - 5 } & PEF & SaO2 & PEF & SaO2 \\
\hline Median Pre & 34.8 & 97 & 35.8 & 97 \\
\hline Median Post & 29.4 & 97 & 36.3 & 96 \\
\hline Paired t test & 0.03 & 0.17 & 0.62 & 0.28 \\
\hline $\begin{array}{c}\text { Independent t test } \\
\text { of PEF }\end{array}$ & & 0.00 & \\
\hline $\begin{array}{c}\text { Independent t test of } \\
\text { SaO2 }\end{array}$ & & 0.10 & \\
\hline
\end{tabular}

This study used the difference in value of peak expiratory flow (PEF) which is the smaller difference between the peak expiratory flow (PEF) at night and morning, the better peak expiratory flow (PEF) value. Research by Parmar \& Nagarwala, (2014) in which the peak expiratory flow values obtained using spirometry thus increasing interpreted with increasing peak expiratory flow values (PEF) before and after Yoga Pranayama exercises $(\mathrm{t}=4.03, \mathrm{p}<0.05)$ [5]. Research [13] using the same research methods with Parmar \& Nagarwala which explained the increase in peak expiratory flow (PEF) after doing Yoga Pranayama exercise $(\mathrm{P}=0.02, \mathrm{P}$ $<0.001$, and $\mathrm{P}<0.001)$.

Yoga Pranayama exercises consist of the inspiration process, hold, expiratory and respiratory muscles. The process will lead to increase of tidal volume in the lungs so that oxygen partial pressure increase. Then chemoreceptors read the decreased levels of $\mathrm{CO} 2$, sends a signal to the medulla oblongata, pons which causes the rhythm and breathing muscles become slow and deep. Decreased levels of $\mathrm{CO} 2$ also causes an increase in parasympathetic nerves work, so bronchodilators happened [14] [15].

When someone breaths (inhale), oxygen will enter into the respiratory tract through the nose, trachea, bronchus and enter the air sacs (alveoli) which are contained in the lungs. The alveoli covered by blood vessels, so that the oxygen which entering the alveoli will enter into the blood vessels and binds the red blood cells. Red blood cells which rich in oxygen flow throughout the body and brain. Increasing the amount of oxygen supply will eliminate $\mathrm{CO} 2$, which will decrease its stimulation of the sympathetic nervous system and adrenal medulla through a decrease in norepinephrine and epinephrine. When the body starts to relax, breathing becomes slow and deep, so breathing rhythm slows down, heart rate will go more slowly and regularly. The sympathetic nervous system is always ready for action to receive messages to relax, and then the parasympathetic nervous system will respond to relaxation. After experiencing the relaxation of the body, the vital energy of the body becomes balanced, reduced fatigue, thoughts and emotions become quiet [16].

Slow respiratory rhythm, deep breathing muscles and comfortable and relaxed atmosphere will provide optimal ventilation. Optimal ventilation occurs when patient with asthma is doing Yoga Pranayama. Normally a person only uses $10-15 \%$ of our ability to breathe every day. Yoga exercises will increase the amount of air exchange in the lungs which lead to increase in partial pressure of oxygen in the alveoli so that diffusion in the alveoli and capillaries increases. In normal conditions, the amount of air entering the lungs in one minute is as much as $16 \times 400 \mathrm{ml}$, while at the time of doing yoga exercises number increased up to 4 x $4800 \mathrm{ml}$. [14].

In this study, the value of the daily variability of peak expiratory flow (PEF) in 2 respondents from the intervention group decreased significantly from 35.89 into 22.22 and 37.03 into 20.68. This occurs because the age of the respondents younger than one respondent from the intervention group which experience decrease in daily variability of peak 
expiratory flow (PEF) is very small from 34.48 into 33.33. Theoretically muscle strength respiratory and lung function will decrease according to age, this was due to a decrease the elasticity of the chest wall, decreased elasticity of the alveoli, thickening glands bronchial, decreased lung capacity and increased the amount of dead space [7].

In this study, the mean value of the daily variability Peak expiratory flow (PEF) in the intervention group-sex male larger than females. Respiratory muscle strength and lung function of males are higher than the $20 \%-25 \%$ of women, because of the size of the male anatomy lung higher than for women (Guyton \& Hall 2001; slave \& Gallo 2005) (Sahat 2011).

In this study, respondents who had height of $\geq 165 \mathrm{~cm}$ and weight $\geq 65 \mathrm{~kg}$ has a value of peak expiratory flow (PEF) higher than respondents who had height of $<165 \mathrm{~cm}$ and weight $<65 \mathrm{~kg}$. Height and weight also influence muscle strength and lung function, in which a person who has a large high body functions will have a higher lung ventilation. The function of inspiration and expiration is also influenced height and weight as the ability to inflate the chest will be different at each height and weight (Guyton \& Hall 2001; slave \& Gallo 2005) (Sahat 2011). In this study, only age that has significant value to the peak expiratory flow (PEF). Height and weight did not have significant value.

Yoga Pranayama breathing techniques were performed in 2 weeks two days once for 45-minute could significantly decrease the difference between peak expiratory flow (PEF) evenings and mornings so it can reduce the value of the daily variability Peak expiratory flow (PEF). To further optimize the results of Yoga Pranayama exercises, it should be done two times a week in the morning [5] for seven weeks [17], based on yoga instructor, yoga exercises should be performed routinely to obtain optimal results. Based on this research, it is expected the nurse can make rehabilitation programs and promotion of asthma patients since patients admitted to the hospital until the patient went home with the involvement of another health team. One of the rehabilitation programs is teaching Yoga Pranayama exercise, as management for longterm asthma control.

\section{B. EFFECT OF YOGA PRANAYAMA IN SAO2}

Statistical analysis showed there was no effect of Yoga Pranayama exercises on Oxygen Saturation $(\mathrm{SaO} 2)$ in the intervention group who performed Yoga Pranayama and control group who did not perform Yoga Pranayama with $p$ value $=0.17$ and 0.28 with $\alpha=0.05$. Table 5.10 described the results of independent $t$ test and obtained that post-test results of oxygen saturation between intervention and control groups were no different with $\mathrm{p}$ value $=0.10, \alpha=0.05$. Based on the data above, it can be concluded these results do not correspond with the hypothesis 2 . This study is consistent with research by Priyanto (2010) which explained the absence of Deep Breathing Exercise effect which is the breathing exercises such as Yoga Pranayama on the value of Saturation oxygen $(\mathrm{SaO} 2)(\mathrm{P}=0.100)$.

The result showed that was no significant difference between Oxygen Saturation $(\mathrm{SaO} 2)$ in the pre test and post test between the intervention group and the control group. Many things can affect changes in oxygen saturation ( $\mathrm{SaO} 2)$, including the cardiovascular system and hematology, and lung function status [18]. The ability of the cardiovascular system and hematologic can be identified from the picture of hemodynamic and $\mathrm{Hb}$ levels, which play a role in the transport of oxygen. Pulmonary function was identified from the ability to provide oxygen gas exchange in the alveoli, so those three things mutually sustainable for determining the value of Oxygen Saturation $(\mathrm{SaO} 2)[19]$.

This research used pulse oximetry to measure the value of Oxygen Saturation (SaO2) where the accuracy of pulse oximetry value is directly related to perfusion in the probe area. The results of oximetry measurements on clients with poor tissue perfusion are due to shock, hypovolemia or peripheral vascular disease may be invalid [20]. Oxygen saturation in patients with asthma is influenced by (1) the cardiovascular circulatory disorders [18]. In patients with chronic asthma is usually accompanied by a heart disorder that affects the body's ability to meet the oxygen. (2) The increase in the rate of metabolism. The increase in the metabolic rate of the body in response to increased effort to breathe, causing increased oxygen demand being offset by the ability of the body's systems to meet the increasing needs of the body's oxygen. (3) Anemia. Decreased levels of hemoglobin in the blood cause a reduction in oxyhemoglobin carrying blood ties. Reduced affect the value of this bond oxygen saturation (SaO2) of blood. (4) Decrease the inspired oxygen concentration. Upper airway obstruction and down due to bronchospasm will limit the transport of oxygen from the external environment into the alveoli. This will affect the partial pressure of the gas which decreases the gas diffusion process.

The process of oxygen transport and tissue oxygenation is directly affected by the cardiovascular system and hematologic supported with adequate pulmonary function, besides Oxygen Saturation (SaO2) is determined by oxyhemoglobin chemical processes in the body. Examination of Oxygen Saturation ( $\mathrm{SaO} 2)$ by pulse oximetry is one of the pulmonary function tests to determine the ability of oxygen. Pulse oximetry can not replace arterial blood gas analysis but it is an effective way to monitor the oxygen clients are often used in intensive care units [21]. Oxygen Saturation value during Yoga Pranayama exercises showed that the Yoga Pranayama exercises did not affect the impairment of Oxygen Saturation ( $\mathrm{SaO} 2)$ below normal, meaning no adverse effects of Yoga Pranayama exercises. The results showed no statistically significant difference, but the value of Oxygen Saturation ( $\mathrm{SaO} 2)$ can be maintained normally. In this study, approximately $66.66 \%$ oxygen saturation $(\mathrm{SaO} 2)$ fixed the intervention group.

Almost nobody has decreased Oxygen Saturation ( $\mathrm{SaO} 2)$ in the intervention group, while in the control group one respondent experienced a significant decrease in oxygen saturation $(\mathrm{SaO} 2)$ of 97 into 94 . This is because at the time of the post-test respondents experienced tightness in early on the morning of the day due to the weather in respondent place is cold. Cold is a factor that can cause asthma attacks resulting in impairment of Oxygen Saturation $(\mathrm{SaO} 2)$. 


\section{CONCLUSION}

Yoga Pranayama affect the increased of Peak Expiratory Flow (PEF) due to an increase in tidal volume but the saturation of oxygen $(\mathrm{SaO} 2)$ there was no significant effect which may be due to factors that affect the value of oxygen saturation ( $\mathrm{SaO} 2)$ : (1) cardiovascular circulatory disorders (2) increase in rate of metabolism (3) anemia (4) decrease in inspired oxygen concentration.

\section{References}

[1] I. Rengganis, "Diagnosis dan Tatalaksana Asma Bronkial," Maj. Kedokt. Indones., vol. 15, no. 2, pp. 444-451, 2008.

[2] Ministry Of Health, Pharmaceutical Care Untuk Penyakit Asma. Jakarta: Direktorat Bina Farmasi Komunitas dan Klinik DITJEN Bina Kefarmasian dan Alat Kesehatan Departemen Kesehatan RI, 2007.

[3] I. R. Nikmah, S. N., Purba, A., \& Defi, "Efektivitas latihan Incentive Spirometry dengan latihan pernafasan diafragma terhadap fungsi paru, kapasitas fungsional, dan kualitas hidup penderita asma bronkial alergi," $M K B$, vol. 46, no. 1, p. 39-47., 2014.

[4] Y. Chen, D. C. Rennie, P. Pahwa, and J. A. Dosman, "Pulmonary function in adults with recent and former asthma and the role of sex and atopy," BMC Pulm. Med., vol. 12, no. 1, p. 32, Dec. 2012.

[5] J. Parmar and R. Nagarwala, "Effects of Pranayama on Bronchial Asthma," Int. J. Physiol., vol. 2, no. 1, p. 96, 2014.

[6] S. H. Nagarchi, K., Ahmed, S., \& Saheb, "Study of Pulmonary Function Test in Asthma Patients," $J$. Pharm. Sci. Res., vol. 7, no. 1, pp. 37-39, 2015.

[7] S. P. Sahat, C. S., Irawaty, D., \& Hastono, "Peningkatan Kekuatan Otot Pernapasan dan Fungsi Paru Melalui Senam Asma pada Pasien Asma," J. Keperawatan Indones., vol. 14, no. 2, pp. 101-106, 2011.

[8] Kementerian Kesehatan RI, "Riset Kesehatan Dasar Dalam Angka-Riskesdas 2013," 2013.

[9] W. e Atmoko, "Pravelens Asma Tidak Terkontrol dan Faktor-Faktor yang Berhubungan dengan Tingkat Kontrol Asma di Poliklinik Asma Rumah Sakit Persahabatan," J. Respirologi Indones., vol. 31, no. 2, 2011.
[10] I. K. Darmayasa, "Senam Asma Tiga Kali Seminggu Lebih Meingkatkan Kapasitas Vital Paksa (KVP) dan Volume Ekspirasi Paksa Detik 1 (VEP1) dari Pada Senam Asma Satu Kali Seminggu pada Penderita Asma Persisten Sedang," Maj. Ilm. Fisioter. Indones., vol. 1 , no. $1,2013$.

[11] D. Taneja, "Yoga and health," Indian J. Community Med., vol. 39, no. 2, p. 68, 2014.

[12] K. A. Kondam, Ambareesha; M, Chandrasekhar; G, Purushothaman; S, Qairunnisa; N, "A Study to Evaluate the Effect of Vital Capacity (VC), Forced Vital Capacity (FVC) and Peak Expiratory Flow Rate (PEF) in Subjects Practicing Pranayama," Int. J. Curr. Res. Rev., vol. 4, no. 19, p. 154, 2012.

[13] G. Gaur, V. Sharma, T. Madanmohan, K. Harichandra Kumar, T. Dinesh, and A. Bhavanani, "Comparative effect of 12 weeks of slow and fast pranayama training on pulmonary function in young, healthy volunteers: A randomized controlled trial," Int. J. Yoga, vol. 8, no. 1, p. 22, 2015.

[14] M. Wiadnyana, The Power of Yoga For Middle Age. Jakarta: Grasindo, 2010.

[15] L. Sherwood, Fisiologi Manusia Dari Sel ke Sistem Edisi 6. Jakarta: EGC, 2011.

[16] M. S. Ririn, "Pengaruh Yoga Pranayama Terhadap Tingkat Kecemasan Siswi Yang Mengalami Premenstrual Syndrome di SMA Negeri 4 Singaraja," Universitas Airlangga, 2012.

[17] M. P. Jiandani, R. D. Mahulkar, A. U. Athavale, and A. A. Mehta, "Yoga versus Physiotherapy: Effect on Pulmonary function, Breath Holding Time \&amp; Quality of Life in Asthmatics," Indian J. Physiother. Occup. Ther. - An Int. J., vol. 7, no. 4, p. 160, 2013.

[18] L. . Price, Sylvia A., \& Wilson, Pathofosiologi: Konsep Klinis Proses-Proses Penyakit. Jakarta: EGC, 2006.

[19] Priyanto, "Pengaruh Deep Breathing Exercise Terhadap Fungsi Ventilasi Oksigenasi Paru Pada Klien Post Ventilasi Mekanik," Universitas Indonesia, 2010.

[20] E. Emaliyawati, "Pengaruh Latihan Nafas Dalam Terhadap Konsentransi Oksigen Darah di Perifer pada Klien Tuberkulosis," Bandung, 2009.

[21] S. C. Smeltzer and B. G. Bare, Buku Ajar Keperawatan Medikal Bedah Brunner \& Suddarth. Jakarta: EGC, 2009. 